\title{
Pathogenicity of a Species of Phomopsis Causing a Shoot Blight on Peach in Georgia and Evaluation of Possible Infection Courts
}

\author{
W. Uddin and K. L. Stevenson, Department of Plant Pathology, University of Georgia, Athens 30602; and R. A. \\ Pardo-Schultheiss, Systematic Botany and Mycology Laboratory, USDA/ARS, B011A BARC-West, Beltsville, \\ MD 20705
}

\begin{abstract}
Uddin, W., Stevenson, K. L., and Pardo-Schultheiss, R. A. 1997. Pathogenicity of a species of Phomopsis causing a shoot blight on peach in Georgia and evaluation of possible infection courts. Plant Dis. 81:983-989.

A species of Phomopsis was isolated consistently from blighted shoots of peach trees in Georgia and Alabama. Isolates of the fungus caused characteristic cankers on current season's shoots of Babygold-7 peach trees when wounded or nonwounded dormant buds, breaking buds, and natural or artificially-created leaf scars were inoculated with conidia of the fungus. Mean canker length for the isolates was $35 \mathrm{~mm} 30$ days after inoculation. No disease developed on control trees. There was no significant difference between the canker length on inoculated wounded dormant buds $(59 \mathrm{~mm})$ and nonwounded breaking buds $(54 \mathrm{~mm})$. However, cankers from both sites of inoculation were significantly longer than those resulting from inoculated artificiallycreated leaf scars $(33 \mathrm{~mm})$, natural leaf scars $(33 \mathrm{~mm})$, and non-wounded dormant buds (30 $\mathrm{mm}$ ). There was no significant difference in virulence among the 5 isolates of Phomopsis sp. tested, and multi-locus DNA fingerprint analysis resulted in a similarity coefficient of 0.94 among the isolates. Additionally, results of the internal transcribed spacer (ITS) regions sequence comparisons for the isolates were consistent with the multi-locus polymerase chain reaction profiles, and the nucleotide sequences of the ITS region were identical for all 5 isolates. This is the first documentation of the pathogenicity of a Phomopsis sp. associated with shoot blight of peach in Georgia. Rapid development of disease in breaking buds indicates that they may be the primary site of invasion by the fungus. Natural leaf scars and dormant buds may also serve as possible infection courts.
\end{abstract}

Additional keyword: Prunus persica

Shoot blight has become an increasing problem in the peach (Prunus persica (L.) Batsch) production regions of the southeastern United States. Severe decline of peach trees has occurred due to the loss of blighted shoots in north Georgia (Figs. 1A and B), and it has become more prevalent in central Georgia in recent years. A number of peach diseases with symptoms similar to shoot blight in Georgia, such as peach canker, constriction disease, and constriction canker in the Midwest and mid-Atlantic States, shot hole in California, and dieback in Europe have been reported $(3,4,6,7,11,12,16,18,29)$. There has been some confusion over the identity of these shoot diseases, and various fungi such as Phoma persicae, Phomopsis

Corresponding author: W. Uddin

E-mail: wuddin@uga.cc.uga.edu

American Type Culture Collection accession number 200995.

GenBank accession number U86406.

Accepted for publication 24 May 1997.

Publication no. D-1997-0717-02R

(C) 1997 The American Phytopathological Society amygdalina, a Phomopsis sp., Fusicoccum amygdali, and Wilsonomyces carpophilus that have been reported to be associated with these symptoms.

A disease of peach called bud and shoot blight was first reported from Georgia in 1989 (8). This was followed by a report of a disease from Alabama in 1993 named shoot dieback (10). Both reports indicated that a species of Phomopsis was associated with the diseased shoots. The conclusions were based on frequency of isolation of the fungus from diseased tissue, rather than from a complete pathogenicity study on live peach trees. This disease was reported in Georgia four decades after the first reports of constriction disease from Delaware and Maryland, and it is unknown whether these diseases are related.

It was observed in the field in Georgia and Alabama that necrotic lesions initially develop on shoots where buds, leaf scars, and bloom scars are located. However, it is unclear which of these tissues serves as the primary infection court for the fungus. In 1956, it was reported from New Jersey that infection of peach shoots by $F$. amygdali occurred through the bud scales, stipules, fruit and leaf scars, and the blooms in a shoot disease of peach named "peach canker disease" (4). Therefore, it was impor- tant to determine which components of a shoot serve as the primary infection courts for the pathogen of shoot blight of peach.

This study was undertaken to determine the pathogenicity of the fungi associated with this disease, the primary sites for invasion of the shoots by the fungus, and morphological and molecular characterization of the pathogen.

\section{MATERIALS AND METHODS}

Symptomatology and isolation of fungi from diseased tissue. Diseased shoots of peach trees in Georgia and Alabama were photographed in 1993 and 1994 to illustrate the symptoms of shoot blight. In March 1994, peach shoots of current season's growth with shoot blight symptoms were collected from orchards of peach cultivars Dixieland, Elberta, and Georgia Belle in Hall County, Georgia; Blake in Oconee County, Georgia; Sunprince and Topaz in Peach County, Georgia; and Georgia Belle in Chilton County, Alabama. Fifty shoots were collected from each location, placed in a cooler, and brought to the laboratory for isolation. Shoots with cankers were washed thoroughly in tap water, blotted dry, cut into segments ( 8 to $10 \mathrm{~cm}$ in length), and surface-disinfested by immersing in $0.5 \%$ $\mathrm{NaOCl}$ for $3 \mathrm{~min}$. Tissue pieces of approximately 2 by 2 by $4 \mathrm{~mm}$ were removed from the leading edge of necrotic zones from beneath the bark with a sterile scalpel, and transferred to water agar. After 5 days, agar blocks containing the growing tips of young hyphae were transferred to potato-dextrose agar (PDA). Identification of the isolated fungi was made on 2- to 4week-old cultures. Five representative isolates of a Phomopsis sp. (based on colony characteristics) from each geographic location (Hall, Oconee, and Peach County, Georgia, and Chilton County, Alabama) were selected for further evaluation. Each isolate was transferred to PDA, corn meal agar, oatmeal agar, V8 juice agar, and peach fruit agar, which was prepared using the procedure similar to that used for V8 juice agar. Firm flesh of ripe Dixieland peaches was pureed in a blender and 200 $\mathrm{ml}$ of the puree, $2 \mathrm{~g} \mathrm{CaCO}_{3}$, and $15 \mathrm{~g}$ Difco agar were added to $800 \mathrm{ml}$ distilled water to make 1 liter of medium. The medium was autoclaved and $\mathrm{pH}$ was adjusted to 5.5 with $\mathrm{HCl}$ or $\mathrm{NaOH}$. Additionally, isolates were grown on autoclaved and dried alfalfa 
stems and peach shoots (4 $\mathrm{cm}$ in length), which were maintained on water agar. All cultures were incubated at 10, 20, and $30^{\circ} \mathrm{C}$ under fluorescent and incandescent lights $\left(256 \mu \mathrm{E} \mathrm{m}^{-2} \mathrm{~s}^{-1}\right) 12 \mathrm{~h}$ per day for 3 weeks, and at room temperature (20 to $22^{\circ} \mathrm{C}$ ) under continuous fluorescent light $\left(210 \mu \mathrm{E} \mathrm{m}^{-2} \mathrm{~s}^{-1}\right)$ for 16 weeks, and examined for production of $\beta$-conidia. Each isolate also was maintained on Dixieland, Georgia Belle, Monroe, and Southland peach fruits for 10 days, and on autoclaved and dried alfalfa stems and peach shoots for over a year at 20 to $22^{\circ} \mathrm{C}$. Other fungi isolated from peach shoots were maintained on PDA for 6 to 8 weeks at 20 to $22^{\circ} \mathrm{C}$ and identified.

Pathogenicity studies. Five selected isolates of the Phomopsis sp. (GAB01, GLB06, GLS14, GFS23, and ACG11), and isolates of the anamorphs of Botryosphaeria dothidea, B. rhodina, B. obtusa, and a Cytospora sp. were selected for pathogenicity tests. Monoconidial isolates of the fungi were maintained on PDA in an incubator at $20^{\circ} \mathrm{C}$ under fluorescent light $\left(110 \mu \mathrm{E} \mathrm{m}^{-2} \mathrm{~s}^{-1}\right)$ for 3 weeks. One-year-old Babygold-7 trees on Lovell rootstock were planted in 11-liter plastic pots with a mix of sand:soil:pine bark $(1: 1: 1, \mathrm{vol} / \mathrm{vol} / \mathrm{vol})$ and maintained in the greenhouse $\left(24 / 18^{\circ} \mathrm{C}\right.$, day/night). Trees were fertilized with water soluble 20-8.8-16.6 (N-P-K) fertilizer at the rate of $1.44 \mathrm{~g}$ per tree every 2 weeks.

The current season's shoots of 1-yearold Babygold-7 peach trees were wounded and inoculated according to a procedure described by Weingartner and Klos (26). The base of the petiole and the associated buds were dissected horizontally using a sterile scalpel, and the upper two-thirds of the buds and the petiole base were removed. The cut area and the surrounding shoot surface were disinfested with $25 \%$ ethanol and blotted dry. A V-shaped incision was made at a $45^{\circ}$ angle using a sterile scalpel at the dissected area to expose the tissue under the bark. An agar plug (4 by $4 \mathrm{~mm}$ ) containing young hyphae of a 12-day-old culture was placed inside the Vshaped incision, wrapped with sterile, moist cheesecloth, and sealed with Parafilm. Three shoots from each tree and three trees were inoculated with each of the isolates. Control trees were treated similarly with sterile blocks of PDA. The inoculation treatments were arranged in a randomized complete block design with five replications. Ten days after inoculation, the cheesecloth and Parafilm were removed and disease was evaluated by measuring the length of each canker 10 and 28 days after inoculation. The inoculated shoots were then removed from the trees and the fungi were reisolated. The experiment was repeated once.

Inoculation of possible sites of infection. Five different sites of inoculation were tested: breaking buds, nonwounded dormant buds, wounded dormant buds, prematurely created leaf scars, and natural leaf scars. New sets of 2-year-old Babygold-7 peach trees on Lovell rootstock were maintained outside the greenhouse throughout the summer of 1995 . On 16 October 1995, the trees marked for inoculation of breaking buds were moved to the greenhouse $\left(26 / 18^{\circ} \mathrm{C}\right.$, day/night). After 2 weeks, the remaining trees were moved to the greenhouse, and inoculation of the trees for all the sites of inoculation was performed at the same time. Breaking vegetative buds with no visible green tips were selected for inoculation. Dormant buds were wounded by dissecting them horizontally and removing the upper twothirds. Premature leaf scars were created by manually detaching leaves and petioles from the shoot. Natural leaf scars were selected for inoculation from the shoots where natural defoliation of the leaves had occurred in October 1995. A drop (approximately $0.035 \mathrm{ml}$ ) of conidial suspension $\left(10^{5} \alpha\right.$-conidia $/ \mathrm{ml}$ sterile distilled water) of the Phomopsis isolate GLB06 (ATCC accession number 200995) was placed on each of the inoculation sites, wrapped with moist cheesecloth, and sealed with Parafilm. For each site, 5 shoots of current season's growth per tree were inoculated, and the inoculation treatments were replicated five times with one tree per replication. Control trees were treated with sterilized distilled water. The inoculation treatments were arranged in a randomized complete block design. Ten days after inoculation, cheesecloth and Parafilm were removed, and canker length measured. Disease evaluations were repeated twice at 10-day intervals.

The experiment was repeated in March 1996 with slightly modified sites of inoculation. The sites of inoculation were breaking buds, nonwounded dormant buds, wounded dormant buds, prematurely created bloom scars, and natural bloom scars. Babygold-7 peach trees were maintained outside the greenhouse throughout the winter. The trees marked for inoculation of dormant buds and breaking buds were moved to a growth chamber $\left(10^{\circ} \mathrm{C}\right)$ in early February to maintain dormancy of the buds. Trees marked for inoculation of breaking buds were moved to the greenhouse 1 week prior to inoculation. Trees marked for inoculations at prematurely created bloom scars and natural bloom scars were moved to the greenhouse $\left(24 / 18^{\circ} \mathrm{C}\right.$, 12-h day/night) when the remaining flower buds opened after the initial blossoms were killed by freezing temperature in March. Prematurely created bloom scars, formed by removing the fully expanded flowers from the shoot, and sites for inoculation of natural bloom scars were selected from the shoot where the dead blooms had abscised. The sites for inoculation of breaking flower buds with no visible pink tip were selected on the shoots. The trees marked for inoculation of nonwounded and wounded dormant buds were transferred from the growth chamber to the greenhouse $1 \mathrm{~h}$ before inoculation. Buds were wounded and inoculated as in the previous experiment. Ten days after inoculation, disease severity was evaluated by measuring the length of the cankers. Evaluations were repeated twice at 10-day intervals.

DNA extraction, multi-locus amplification and sequencing. DNA was extracted from mycelia of the 5 monoconidial isolates of the Phomopsis sp. used in the pathogenicity tests. Extraction from mycelia was performed according to the procedures described by Rehner and Samuels (14) and Rehner and Uecker (15).

The polymerase chain reaction (PCR) was used for multi-locus fingerprinting to amplify DNA according to the following protocol: approximately $10 \mathrm{ng}$ of genomic DNA, 25 pmol of either $(\mathrm{GTG})_{5},(\mathrm{GGA})_{7}$, (ACAC) $)_{5}$, or phage M13 core sequence (GAGGGTGGNGGNTCT) oligonucleotide primer, $200 \mathrm{mM}$ total dNTPs, $3 \mathrm{mM}$ $\mathrm{MgCl}_{2}$ and $1.25 \mathrm{U}$ Taq polymerase (Promega Corporation, Madison, WI). PCR reactions were carried out in a total reaction volume of $25 \mu \mathrm{l}$, overlaid with mineral oil. Thermal cycling was performed on a PTC-100 (MJ Research, Inc., Watertown, MA) using the following parameters: an initial incubation at $94^{\circ} \mathrm{C}$ for $2 \mathrm{~min}$, followed by 40 cycles of $30 \mathrm{~s}$ at $93^{\circ} \mathrm{C}, 1 \mathrm{~min}$ at $53^{\circ} \mathrm{C}, 30 \mathrm{~s}$ at $72^{\circ} \mathrm{C}$, and a final $72^{\circ} \mathrm{C}$ extension period of $10 \mathrm{~min}$. PCR for the amplification of the internal transcribed spacer (ITS) regions included $10 \mathrm{ng}$ of genomic DNA, $25 \mathrm{pmol}$ each ITS5 and ITS4 primers (28), $200 \mathrm{mM}$ (each) dNTPs, $1.5 \mathrm{mM} \mathrm{MgCl}$ and $1.25 \mathrm{U}$ Taq polymerase. PCR reactions were carried out in a total reaction volume of $50 \mu \mathrm{l}$ overlaid with mineral oil. The cycling parameters were: incubation at $94^{\circ} \mathrm{C}$ for 2 min, followed by 32 cycles of $30 \mathrm{~s}$ at $93^{\circ} \mathrm{C}$, $30 \mathrm{~s}$ at $54^{\circ} \mathrm{C}$, and $1 \mathrm{~min}$ at $72^{\circ} \mathrm{C}$, and a final $72^{\circ} \mathrm{C}$ extension period of $10 \mathrm{~min}$. The ITS fragments were sequenced with primers ITS5 and ITS4 using the Taq Dyedeoxy Terminator Kit (Perkin Elmer/Applied Biosystems, Foster City, CA) and the nucleotide sequences were analyzed with an ABI 310 automated sequencer (Perkin Elmer/Applied Biosystems).

Multi-locus fingerprint analysis. Amplification products were separated electrophoretically on an agarose gel containing 1\% Metaphor (FMC Bioproducts, Rockland, ME) and $0.5 \%$ standard agarose in $1 \times$ TBE. The gel was stained with ethidium bromide, and the DNA was visualized with ultra-violet irradiation and photographed. Photographic negatives were examined visually and banding patterns compared. Similarity coefficients were obtained using the following formula: $S=2 N_{\mathrm{ab}} /\left(N_{\mathrm{a}}+N_{\mathrm{b}}\right)$, where $N_{\mathrm{a}}$ and $N_{\mathrm{b}}$ represent the total number of fragments for the species compared and $N_{\mathrm{ab}}$ represents the number of fragments in common (27). 
Sequence analysis. Nucleotide sequences were edited, joined and aligned using EditSeq, SeqMan, and MegAlign modules in the LaserGene sequence software (DNAStar, Inc., Madison, WI).

Statistical analysis. Canker lengths for each experiment were subjected to analysis of variance. Multiple comparisons of dis- ease severity for the sites of inoculation were made using Student-Newman-Keul's test $(\alpha=0.05)$. The statistical procedures were conducted using the Statistical Analy-
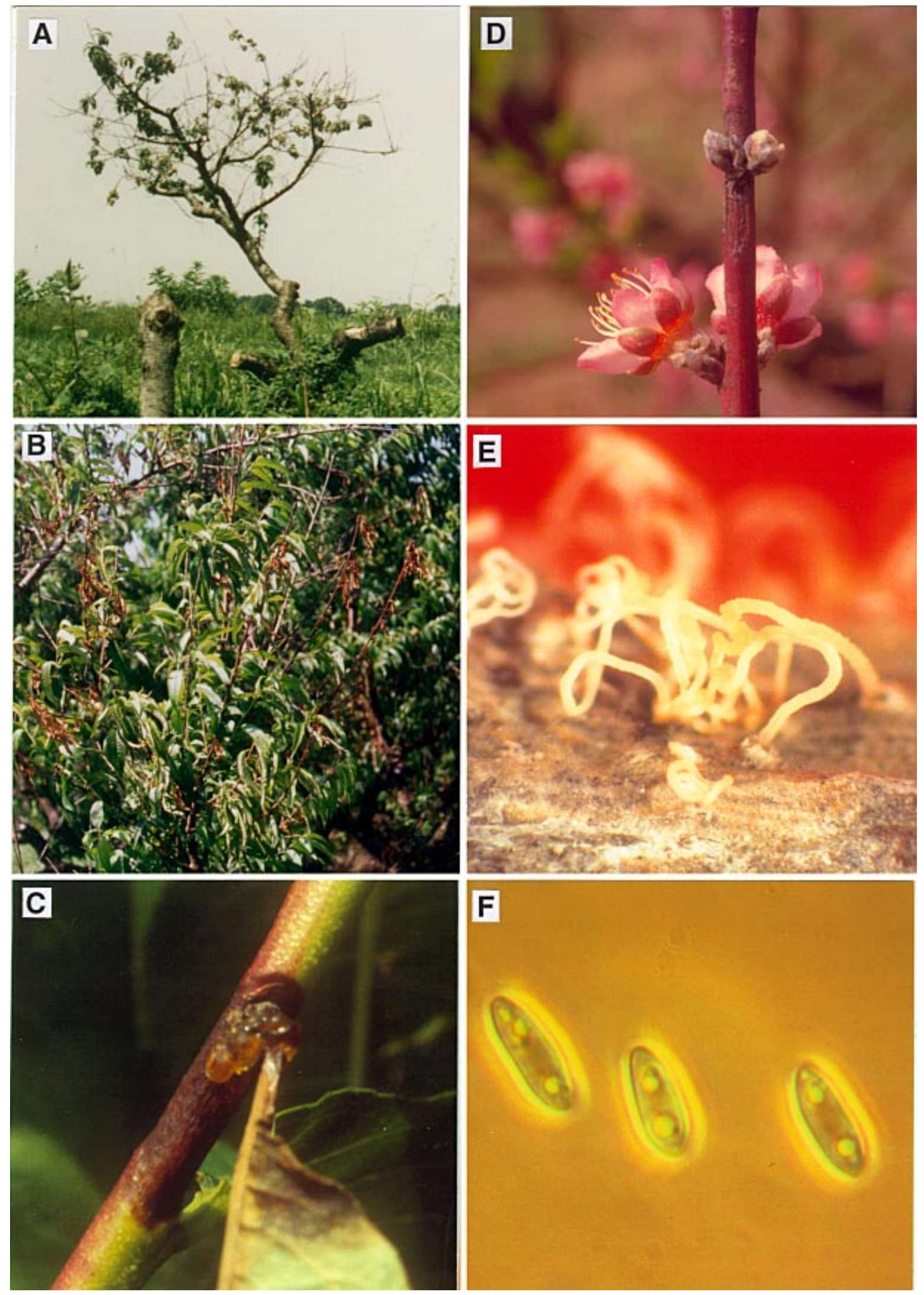

Fig. 1. (A) Decline of 8-year-old Dixieland peach tree affected by shoot blight caused by Phomopsis sp., (B) blighting of current season's shoots of Georgia Belle peach resulting from infection by the fungus, (C and D) development of necrosis centered around the bud on current season's shoot of Dixieland peach in early fall and spring, (E) cirri produced by pycnidia of Phomopsis sp. on infected shoot of Dixieland peach, and (F) $\alpha$-conidia of Phomopsis sp. 
sis System software (SAS Institute, Cary, $\mathrm{NC}$.

\section{RESULTS}

Symptomatology and isolation of fungi from diseased tissue. The symptoms of peach shoot blight in the field develop initially as necrosis on current season's shoots centered around the vegetative and flower buds and the leaf petiole (Figs. 1C and D). The canker usually develops a zonate pattern with numerous pycnidia that form in the spring and produce cirri (Fig. 1E) containing $\alpha$-conidia (Fig. 1F) under humid conditions. The necrotic lesion expands rapidly, disrupts the vascular tissues, and causes the shoot to wilt. Occasionally, necrosis may originate from the growing tips of young shoots, but downward progression of the canker is limited to only a few centimeters below the shoot tip. A Phomopsis sp. was the predominant fungus isolated from cankers on peach shoots, followed by $B O$ tryosphaeria spp. and a Cytospora sp. The shoots from the seven locations yielded mean isolation frequencies of $91 \%$ Phomopsis sp., 56\% Botryosphaeria spp., 17\% Cytospora sp., and 6\% unidentified fungi. Isolates of the Phomopsis sp. were concentric and creamy white on PDA at 20 to $22^{\circ} \mathrm{C}$. Conidiomata ( 155 to 260 by 110 to $215 \mu \mathrm{m}$ ), conidiogenous cells (10 to 17.5 by 1.25 to $2.5 \mu \mathrm{m}$ ), and $\alpha$-conidia ( 7.5 to 10 by 2.5 to $3.75 \mu \mathrm{m}$ ) were produced in abundance within 7 days. Alpha-conidia were hyaline, fusiform-elliptic to oblongelliptic, and biguttulate; however, conidia with uni- or multiguttules were occasionally found. No $\beta$-conidia were detected on any of the isolates grown on various media incubated at three different temperatures for 3 weeks, or on peach fruits for 10 days, or on alfalfa stems and peach shoots over a year. Species of Botryosphaeria included the anamorphs of $B$. dothidea, B. obtusa, and $B$. rhodina. The species of Cytospora was not characterized further.

Pathogenicity test. Ten days after inoculation, cankers typical of those observed in the orchard developed on shoots inoculated with each of the isolates of the Phomopsis sp. There was no significant difference $(\alpha=0.05)$ in canker length (27.3 to $39.5 \mathrm{~mm}$ ) among the 5 isolates. No necrosis developed in shoots inoculated with species of Botryosphaeria or Cytospora, or in control trees. However, a slight discoloration at the surface of the incision point was observed on $13 \%$ and $7 \%$ of the shoots inoculated with $B$. dothidea and B. obtusa, respectively. By 28 days after inoculation, $84 \%$ of the shoots inoculated with the Phomopsis sp. had wilted. There was no evidence of expansion of discoloration beyond the incision point on shoots inoculated with species of Botryosphaeria and Cytospora. Phomopsis sp. was recovered from $92 \%$ of the inoculated shoots. None of the isolates of Botryosphaeria spp. or the Cytospora sp. were recovered from inoculated shoots.

Inoculation of possible infection sites. Cankers developed on all shoots regardless of the site of inoculation. In the 1995 experiment, 10 days after inoculation, cankers resulting from inoculation of wounded dormant buds were significantly longer ( $\alpha$ $=0.05$ ) than those resulting from any other sites of inoculation (Table 1). Cankers that developed from inoculated breaking buds and prematurely created leaf scars were not significantly different; however, they were significantly longer than those resulting from the nonwounded dormant buds and natural leaf scars. Cankers resulting from inoculated nonwounded dormant buds and natural leaf scars were not significantly different. Cankers that developed from inoculated wounded dormant buds or breaking buds were not significantly different in length 20 and 30 days after inoculation, but were significantly longer than those from prematurely created leaf scars, nonwounded dormant buds, or natural leaf scars. Cankers that developed from inoculated prematurely created leaf scars, dormant buds, or natural leaf scars did not differ significantly in length from one another.

In the second experiment in 1996, cankers developed at all sites of inoculation. Ten days after inoculation, cankers resulting from inoculation of wounded dormant buds, breaking buds, and prematurely created bloom scars were not significantly different in length; however, they were significantly longer than those from non- wounded dormant buds or natural bloom scars. Cankers resulting from inoculation of nonwounded dormant buds or natural bloom scars were not significantly different. Cankers at wounded dormant buds and breaking buds 20 and 30 days after inoculation were significantly longer than those at prematurely created bloom scars, which in turn were greater than those at nonwounded dormant buds and natural bloom scars. Canker length at nonwounded dormant buds did not differ significantly from those at natural bloom scars.

Molecular characterization. Results from the multi-locus amplification profiles (Fig. 2) revealed average similarity coefficients of 0.93 for (GTG) $)_{5}$ (Fig. 2A), 0.981 for $(\mathrm{GGA})_{7}$ (Fig. 2B), 0.887 for M13 (Fig. 2C), and 0.958 for (ACAC) 5 (Fig. 2D) (mean similarity coefficient for four multilocus oligonucleotide primers $=0.94$ ). Results of the ITS sequence comparisons for the 5 peach isolates were also consistent with the multi-locus PCR profiles. Nucleotide sequences of the ITS region were identical for all 5 isolates (Figs. 2A through D) sequenced with GLB06 used as the reference isolate (GenBank accession number U86406).

\section{DISCUSSION}

There has been a great deal of uncertainty about the etiology of shoot blight and similar diseases of peach as described in the literature. Symptoms of many of these diseases are characterized by development of a canker on current season's shoots from initial necrosis at a node. Cankers often continue to expand in a zonate pattern surrounding the buds. Occasionally, cankers may cause a slight constriction of the shoot, which appears to be associated with young and tender shoots. Whether constricted or not, the canker eventually disrupts the vascular tissue and causes wilting and death of the shoot. Based on the symptoms, various diseases have been described, such as peach canker $(4,6,7,9)$, constriction canker (12), constriction disease $(16,18,25)$, dieback $(3,10)$ and bud and shoot blight (8), and have been variously reported to be caused by species of Phoma, Phomopsis, or Fusicoccum. Additionally, the symptoms associated with

Table 1. Canker development on current season's peach shoots at different sites of inoculation with Phomopsis sp.

\begin{tabular}{|c|c|c|c|c|c|c|}
\hline \multirow[b]{3}{*}{ Site of inoculation ${ }^{x}$} & \multicolumn{6}{|c|}{ Canker length (mm) } \\
\hline & \multicolumn{3}{|c|}{1995} & \multicolumn{3}{|c|}{1996} \\
\hline & 10 days & 20 days & 30 days & 10 days & 20 days & 30 days \\
\hline Dormant bud (wounded) & $34.1 \mathrm{a}^{\mathrm{y}}$ & $54.4 \mathrm{a}$ & $59.4 \mathrm{a}$ & $42.2 \mathrm{a}$ & $57.0 \mathrm{a}$ & $61.0 \mathrm{a}$ \\
\hline Breaking bud & $26.0 \mathrm{~b}$ & $45.8 \mathrm{a}$ & $54.1 \mathrm{a}$ & $38.0 \mathrm{a}$ & $52.8 \mathrm{a}$ & $57.6 \mathrm{a}$ \\
\hline Prematurely created leaf or bloom scar ${ }^{\mathrm{z}}$ & $21.3 \mathrm{~b}$ & $28.7 \mathrm{~b}$ & $33.2 \mathrm{~b}$ & $32.2 \mathrm{a}$ & $41.0 \mathrm{~b}$ & $47.2 \mathrm{~b}$ \\
\hline Dormant bud (nonwounded) & $6.5 \mathrm{c}$ & $21.5 \mathrm{~b}$ & $29.7 \mathrm{~b}$ & $12.6 \mathrm{~b}$ & $27.2 \mathrm{c}$ & $33.8 \mathrm{c}$ \\
\hline Natural leaf scar & $3.4 \mathrm{c}$ & $23.3 \mathrm{~b}$ & $33.4 \mathrm{~b}$ & $9.4 \mathrm{~b}$ & $22.6 \mathrm{c}$ & $29.2 \mathrm{c}$ \\
\hline
\end{tabular}

${ }^{x}$ Sites were inoculated with an aqueous suspension of $10^{5} \alpha$-conidia/ml. Cankers were measured 10, 20, and 30 days after inoculation.

${ }^{y}$ Each value represents means of 25 observations. Means within a column followed by the same letter are not significantly different according to StudentNewman-Keul's test $(\alpha=0.05)$.

${ }^{\mathrm{z}}$ Leaf scar in 1995; bloom scar in 1996. 
these diseases often resemble some very different diseases such as Cytospora canker (19) and shot hole (11,29), especially when these pathogens infect current season's shoots at the buds.

The difficulty in determining whether these very similar shoot diseases were in fact the same was exacerbated by inconsistencies in characterization of the causal agents. In 1898, the fungus isolated from peach trees affected by constriction disease was described as Phoma persicae Sacc. (18). In 1940 it was identified as a species of Phomopsis and pathogenicity was demonstrated (16). Comparison of the peach isolates with isolates of other Phomopsis spp. from cherry, apple, and pear trees indicated that they resembled one another very closely, and almost all of them produced $\beta$-conidia on corn meal and oatmeal agar (16). The investigator indicated that these isolates were identical to his earlier isolate of Phomopsis mali Roberts, nomen. illeg., non (Schulzer \& Sacc.) Died. from apple. None of the isolates from Georgia and Alabama fit the morphological description of P. mali (23). These isolates did not produce $\beta$-conidia on any of the substrates which were incubated at various temperatures and light intensities, even after 3 to 16 weeks of incubation. Similarly, no $\beta$-conidia were produced on peach fruit after 10 days at 20 to $22^{\circ} \mathrm{C}$, or on alfalfa stems or peach shoots incubated at
20 to $22^{\circ} \mathrm{C}$ for 12 months. Because of the tremendous variation in conidiomata, conidiogenous cells and $\beta$-conidia within the same species of Phomopsis, and similar or overlapping measurements of these characters in many species from different hosts (23), delimitation to species based on these morphological criteria is not reliable.

Guba (6), who investigated a canker of peach from orchards in Massachusetts, compared diseased plant specimens with those from almond from the Rhone River Valley, France. He found that the disease symptoms and the morphology of fungus isolates was identical to the pathogen described by Delacroix (5) in 1905 as Fusicoccum amygdali. Guba found this
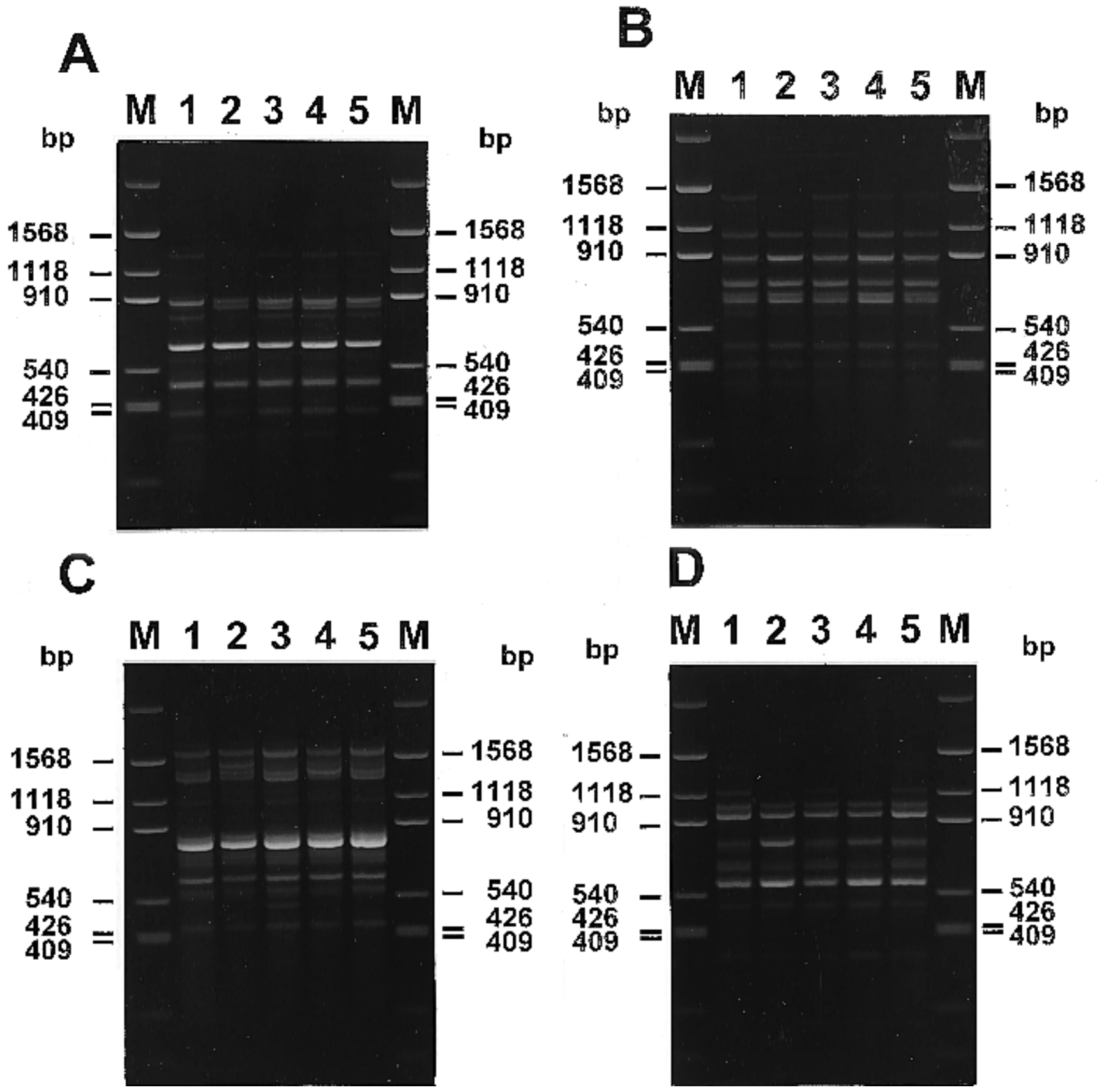

Fig. 2. Ethidium bromide-stained gels of multi-locus amplification profiles for oligonucleotide primers: (A) $(\mathrm{GTG})_{5}$, (B) $(\mathrm{GGA})_{7}$, (C) M13, and (D) $(\mathrm{ACAC})_{5}$. Lanes 1, 2, 3, 4, and 5 represent peach isolates GLB06, GAB01, ACG11, GLS14, and GFS23, respectively. Lane M is the PUC 19 marker. 
pathogen to produce a large, often zonate, brown leaf spot in addition to the characteristic shoot canker. The fungus failed to infect inoculated fruit (6). Contrary to Guba's findings, leaf spot is not associated with the shoot blight of peach in Georgia, and the pathogen was able to infect peach fruit when inoculated (22). This, and the recent description of constriction canker caused by Phomopsis amygdali (Del.) Tuset \& Portilla (synonym Fusicoccum amygdali Del.) (20), leads us to believe that the species of Phomopsis isolated from blighted shoots in Georgia is not the same as the Fusicoccum amygdali Del. that Guba researched in 1953.

The evidence strongly suggests that shoot blight of peach in Georgia is a different disease than those reported from the Midwest and mid-Atlantic states in the late 1800 s and early to mid-1900s $(6,16)$. Sampling of the same orchards in Georgia and Alabama, where bud and twig blight, and dieback of shoots $(8,10)$ were reported, indicates that they are the same as the shoot blight of peach that is prevalent in Georgia. Because the pathogenicity of the Phomopsis sp. was not established previously, it was crucial to complete Koch's postulates by performing inoculation tests on live peach trees. The results of our study confirmed that a Phomopsis sp. is the primary causal agent for this shoot blight disease. All 5 isolates tested were found to be equally virulent on peach. They also were similar in growth and morphological characteristics, including the size and distribution of conidiomata and conidia, and texture and color of the mycelial mat on PDA. The molecular fingerprinting data and sequencing analysis demonstrated a high degree of similarity among the 5 isolates with the use of multi-locus oligonucleotide primers and identical nucleotide sequences of the ITS region, concurring with the results of morphological and virulence studies.

Band sharing similarities among isolates compared can reveal conspecific isolates or interspecific isolates (isolates derived from a single mating population or clones sharing a recent common ancestor). Conspecific isolates share a significant number of common bands, while interspecific isolates share little, if any, similarity in the banding patterns. This information is especially useful when dealing with isolates from various geographic locations.

In this study, we observed an average similarity coefficient of 0.94 among the 5 isolates of the Phomopsis sp., suggesting that the 5 isolates appear to be one species with little or no genetic divergence. Evidence strongly suggests that the isolates are derived from a single mating population. Subsequent nucleotide sequence data concurred with this interpretation, while providing a more accurate phylogenetic relationship among the 5 isolates. Sequencing of the ITS region of the 5 isolates revealed identical nucleotide sequences, which supports the theory of identical species that appear to be derived from a clonal population. A more intensive survey of peach orchards and subsequent molecular fingerprinting and/or sequencing would be necessary to confirm whether this hypothesis is true for all peach orchards infected with shoot blight caused by this species of Phomopsis.

Some species of Botryosphaeria and Cytospora are pathogens of peach that cause perennial cankers in trunks, branches, and shoots $(19,24)$. Some isolates cause cankers in peach trees when wound inoculated $(1,13,17)$. In our study, none of the isolates of Botryosphaeria and Cytospora caused distinct necrosis in inoculated peach shoots, although slight discoloration at the point of incision was sometimes observed. However, areas of discoloration did not expand over the period of 30 days of evaluation and none of these fungi were recovered from discolored tissues after surface sterilization. The isolates of Botryosphaeria spp. and the Cytospora sp. may have failed to cause necrosis because they were saprophytes associated with the branches or limbs of peach trees (13), or 28 days was not long enough for incubation, as suggested by earlier studies $(2,13,17)$, or wounding of shoots in our study was not deep enough.

Cankers developed most rapidly and attained greatest length on the wounded dormant buds, breaking buds, and prematurely created leaf scars, and developed more slowly in the nonwounded dormant buds and natural leaf scars. Rapid development of disease from wounded dormant buds may have been due to the incision which allowed the fungus to readily penetrate and colonize the wood. Slower development of cankers from inoculated prematurely created leaf scars, compared to those from the wounded dormant buds, was probably because wounding of prematurely created leaf scars was not as severe as that of wounded dormant buds. Rapid disease development resulting from inoculation of nonwounded breaking buds indicates that the fungus readily invaded the shoot through the young exposed tissue of the bud. Expansion of cankers at inoculated breaking buds was very rapid and was not different from inoculated wounded dormant buds after 20 days. A similar phenomenon was also observed on shoots with inoculated nonwounded dormant buds and natural leaf scars, where expansion of cankers was very rapid although disease development was slow initially, and cankers were not different from those on shoots with inoculated prematurely created leaf scars 20 days after inoculation. Similar results in the second experiment strongly suggest that the pathogen has the ability to invade the shoot predominantly through breaking buds and that dormant buds, prematurely created leaf or bloom scars, and natural leaf or bloom scars also may serve as infection courts. The trends indicate that initial development of disease may vary depending on the availability of infection sites relative to inoculum, and the severity and impact of the disease in the field by the end of season may be quite similar regardless of site of infection.

The results of field evaluation of possible infection sites correspond well with reported timing of infection in the field (21). The first infection period occurs in the field from mid-March to mid-April, when flower and vegetative buds break and bloom scars are present. The second infection period occurs in early September to mid-October when dormant buds and leaf scars become available.

This is the first documentation of the pathogenicity of a Phomopsis sp. associated with shoot blight of peach. Comparison of DNA fingerprints, nucleotide sequences, morphology, and virulence of the isolates from different geographic locations indicates that a single species of Phomopsis is likely to be involved in this disease. Further studies, particularly those based on molecular techniques, may be necessary to make a valid comparison with the pathogen(s) of peach shoots reported elsewhere.

\section{ACKNOWLEDGMENTS}

Financial support was provided by the Georgia Peach Council. We thank Doug Denney, Marci Scott, and Charles Laster for their assistance in the laboratory and greenhouse experiments.

\section{LITERATURE CITED}

1. Britton, K. O., and Hendrix, F. F. 1982. Three species of Botryosphaeria cause peach tree gummosis in Georgia. Plant Dis. 66:11201121.

2. Britton, K. O., and Hendrix, F. F. 1986. Effects of branch age and wounding on invasion of peach trees with Botryosphaeria spp. (Abstr.) Phytopathology 76:1065.

3. Cayley, D. M. 1923. Fungi associated with "dieback" in stone fruit trees. I. Ann. Appl. Biol. 10:253-274

4. Cohoon, D. F., and Daines, R. H. 1956. Peach canker (Fusicoccum amygdali): Times and sites of infections. Plant Dis. Rep. 40:304-308.

5. Delacroix, G. 1905. Sur une maladie des Amendiers en Provence. Bull. Soc. Mycol. Fr. 21:180-185.

6. Guba, E. F. 1953. Large leaf spot and canker of peach caused by the fungus Fusicoccum amygdali Delarc. Plant Dis. Rep. 37:560-564.

7. Guba, E. F. 1958. Pertinent aspects of the infection cycle and control of the peach canker pathogen, Fusicoccum amygdali. Plant Dis. Rep. 42:481-498.

8. Hendrix, F. F., Jr. 1989. Phomopsis bud and shoot blight of peach. (Abstr.) Phytopathology 79:1154.

9. Hildebrand, E. M. 1947. Perennial peach canker and the canker complex in New York, with methods of control. New York State (Cornell) Agric., Exp. Sta. Memoir 276.

10. Latham, A. J., Morgan-Jones, G., and Campbell, H. L. 1991. Phomopsis dieback of peach shoots in Alabama. Plant Dis. 74:426.

11. Ogawa, J. M., and English, H. 1991. Diseases of Temperate Zone Tree Fruit and Nut Crops. Publ. 3345. University of California, Division of Agriculture and Natural Resources, Oakland. 
12. Ogawa, J. M., Zehr, E. I., Bird, G. W., Ritchie, D. F., Uriu, K., and Uyemoto, J. K. 1995. Compendium of Stone Fruit Diseases. The American Phytopathological Society Press, St. Paul, MN.

13. Pusey, P. L. 1993. Role of Botryosphaeria species in peach tree gummosis on the basis of differential isolation from outer and inner bark. Plant Dis. 77:170-174.

14. Rehner, S. A., and Samuels, G. J. 1994. Taxonomy and phylogeny of Gliocladium analyzed from nuclear large subunit ribosomal DNA sequences. Mycol. Res. 98:625-634.

15. Rehner, S. A., and Uecker, F. A. 1994. Nuclear ribosomal internal transcribed spacer phylogeny and host diversity in the coelomycete Phomopsis. Can. J. Bot. 72:1666-1674.

16. Roberts, J. W. 1940. The constriction disease of peach. Phytopathology 30:963-968.

17. Scorza, R., and Pusey, P. L. 1984. A wound freezing inoculation technique for evaluating resistance to Cytospora leucostoma in young peach trees. Phytopathology 74:569-572.

18. Selby, A. D. 1898. Preliminary reports upon diseases of the peach. Constriction disease of stem and branch. Ohio Agric. Exp. Stat. Res. Bull. 92:233-234.

19. Tekauz, A., and Patrick, Z. A. 1974. The role of shoot infections on the incidence of perennial canker of peach. Phytopathology 64:683688.

20. Tuset, J. J., and Portilla, M. T. 1989. Taxonomic status of Fusicoccum amygdali and Phomopsis amygdalina. Can. J. Bot. 67:12751280.

21. Uddin, W., and Reynolds, K. L. 1996. Evaluation of possible infection courts in shoot blights of peach caused by Phomopsis sp. (Abstr.) Phytopathology 86:S21.

22. Uddin, W., and Reynolds, K. L. 1996. Potential fruit rot of peach caused by the shoot blight pathogen of peach, Phomopsis sp. (Abstr.) Phytopathology 86:S61.

23. Uecker, F. A. 1988. A world list of Phomopsis names with notes on nomenclature, morphology and biology. Mycologia Memoirs No. 13. Cramer Publishers, Berlin.

24. Weaver, D. J. 1974. A gummosis disease of peach trees caused by Botryosphaeria dothidea. Phytopathology 64:1429-1432.

25. Weaver, L. O. 1951. The constriction disease of peach in Maryland. Plant Dis. Rep. 35:144.

26. Weingartner, D. P., and Klos, E. J. 1975 Etiology and symptomatology of canker and dieback diseases on highbush blueberries cause by Godronia (Fusicoccum) cassandrae and Diaporthe (Phomopsis) vaccinii. Phytopathology 65:105-110.

27. Wetton, J. H., Carter, R. E., Parkin, D. T., and Walters, D. 1987. Demographic study of wild sparrow population by DNA fingerprinting. Nature 327:147-149.

28. White, T. J., Bruns, S. L., and Taylor, J. W. 1990. Amplification and direct sequencing of fungal ribosomal RNA genes for phylogenetics. Pages 315-322 in: PCR Protocols: A Guide to Methods and Applications. M. A. Innis, D. H. Gelfand, J. J. Sninsky, and T. J. White, eds. Academic Press, New York.

29. Wilson, E. E. 1937. The shot-hole disease of stone-fruit trees. Calif. Univ. Agric. Exp. Stn. Bull. 608:3-40. 